\title{
Survival of Juvenile Ferruginous Hawks in Utah
}

Author(s): Johanna M. Ward and Michael R. Conover

Source: Journal of Raptor Research, 47(1):31-40.

Published By: The Raptor Research Foundation

DOI: http://dx.doi.org/10.3356/JRR-12-06.1

URL: http://www.bioone.org/doi/full/10.3356/JRR-12-06.1

BioOne (www.bioone.org) is a nonprofit, online aggregation of core research in the biological, ecological, and environmental sciences. BioOne provides a sustainable online platform for over 170 journals and books published by nonprofit societies, associations, museums, institutions, and presses.

Your use of this PDF, the BioOne Web site, and all posted and associated content indicates your acceptance of BioOne's Terms of Use, available at www.bioone.org/ page/terms_of use.

Usage of BioOne content is strictly limited to personal, educational, and noncommercial use. Commercial inquiries or rights and permissions requests should be directed to the individual publisher as copyright holder. 


\title{
SURVIVAL OF JUVENILE FERRUGINOUS HAWKS IN UTAH
}

\author{
Johanna M. WARD And Michael R. Conover ${ }^{1}$ \\ Department of Wildland Resources, Utah State University, Logan, UT 84322 U.S.A.
}

\begin{abstract}
We examined the reproduction of Ferruginous Hawks (Buteo regalis) in Utah's West Desert from 1997-99. We found 100 occupied territories during the study; 80 of them contained an active nest (i.e., evidence of eggs laid). Most active nests (91\%) were successful in producing at least one hatchling, and $67 \%$ of nests with hatchlings produced at least one fledgling. We followed the fate of 202 Ferruginous Hawk hatchlings; $58 \%$ survived to fledging. We radio-tagged 46 of these fledglings; $72 \%$ survived the fledgling period and dispersed from their natal territories. Most juveniles that died were killed during the late nestling $(58 \%)$ and fledgling (24\%) period; mortality was lowest early in the nestling period (18\%). Across all years, $42 \%$ of hatchlings did not survive long enough to disperse from their natal territory. Lagomorph abundance increased each year of our study and during 1999 was over 100 times higher than during 1997. Concomitantly, there was a significant difference among years in the proportion of nests that produced a hatchling and in the survival rate of hatchlings and fledglings. For all of these dependent variables, reproduction was lowest during 1997 when lagomorph densities were low and highest during 1999 when lagomorph densities were high. Yet, most juvenile mortalities were from depredation and not starvation. Most depredated juveniles were apparently killed by avian predators. We also found no relationship between the probability of juvenile depredation and either an index of parental nest attendance or an index of intensity of nest defense.
\end{abstract}

KEY WORDS: Ferruginous Hawk; Buteo regalis; nestling survival; post-fledgling survival; predation-starvation tradeoff; reproductive success; starvation; Utah.

\section{SUPERVIVENCIA DE INDIVIDUOS JUVENILES DE BUTEO REGALIS EN UTAH}

RESUMEN.-Examinamos la reproducción de individuos de Buteo regalis en el West Desert de Utah de 1997 a 1999. Encontramos 100 territorios ocupados durante el estudio, 80 de los cuales contuvieron un nido activo (i.e., evidencia de puesta de huevos). La mayoría de los nidos activos (91\%) tuvieron éxito en producir al menos un polluelo y el $67 \%$ de los nidos con polluelos produjeron al menos un volantón. Monitoreamos el destino de 202 polluelos de B. regalis; el 58\% sobrevivió hasta la etapa de volantón. Marcamos con radio transmisores a 46 de estos volantones; $72 \%$ sobrevivió el período de volantón y se dispersaron de sus territorios natales. La mayoría de los juveniles murieron durante la etapa tardía de pichón (58\%) y el período de volantón (24\%); la menor mortalidad se registró en el período temprano de pichón (18\%). A través de todos los años, el $42 \%$ de las crías recién eclosionadas no sobrevivieron lo suficiente como para dispersarse de su territorio natal. La abundancia de lagomorfos aumentó en cada año de nuestro estudio y durante 1999 fue 100 veces mayor que durante 1997. Concomitantemente, no hubieron diferencias significativas entre años en la proporción de nidos que produjeron una cría y en la tasa de supervivencia de pichones y volantones. Para todas estas variables dependientes, la reproducción fue mínima durante 1997 cuando las densidades de lagomorfos fueron bajas y máxima durante 1999 cuando las densidades de lagomorfos fueron altas. Sin embargo, la mayoría de las muertes de juveniles fueron debidas a la depredación y no a la inanición. La mayoría de los juveniles depredados fueron muertos aparentemente por aves depredadoras. No encontramos relación entre la probabilidad de depredación de un juvenil y tampoco un índice de atención parental al nido o un índice de intensidad de defensa del nido.

[Traducción del equipo editorial]

Predation of juvenile hawks has received little attention as a potential limiting factor of raptor populations, probably because raptor parents are capable of injuring or killing potential predators,

${ }^{1}$ Email address: Mike.conover@usu.edu and most raptor species exhibit nest defense behavior (Newton 1979, Keeley and Bechard 2011). Instead, reproduction in Ferruginous Hawks (Buteo regalis) and other raptors has been assumed to be food-limited due in part to their extended period of parental care (Newton 1979, 1991). However, 
breeding raptors may face a trade-off in attempting to minimize the risk to their offspring of starvation versus depredation (Conover 2007). Indeed, supplemental feeding experiments with raptors suggest that there may be an interaction between starvation and predation (Ward and Kennedy 1994, 1996).

In this study, we examined the potential interaction between food availability and depredation of juvenile Ferruginous Hawks (Buteo regalis) in Utah's West Desert. This hawk is identified as a sensitive species by the U.S. Bureau of Land Management, and the Utah Division of Wildlife Resources lists it as a wildlife species of concern. This hawk population is a good candidate for the study of interactions between starvation and predation because it forages on relatively large mammal species (e.g., rabbits, ground squirrels, and prairie dogs) that exhibit large annual changes in density (Cartron et al. 2004, Giovanni et al. 2007, Schmutz et al. 2008). For example, reproductive success of Ferruginous Hawk in the West Desert is highly correlated with lagomorph (Lepus and Sylvilagus spp.) density (Woffinden and Murphy 1977, Smith et al. 1981, Woffinden and Murphy 1989), and food availability for Ferruginous Hawks in the West Desert fluctuates annually because lagomorph abundance in the region is variable (Gross et al. 1974). We made two predictions about the relationship between parental behavior and the probability of juvenile mortality. First, we predicted that nest attentiveness by adults would increase with increasing food availability. Second, we predicted that increased attentiveness by adults would result in lower depredation rates on their young. Validation of these two predictions is required to establish that parental nest attendance is the mechanism responsible for decreasing predation rates on juveniles as food availability increase. It is not only nest attendance that may be important for offspring survival, but nest defense as well. Hence, we predicted that depredation of juveniles should be reduced if the parents exhibit a high level of nest defense. Here we describe the results of a 3-yr study of Ferruginous Hawk reproduction and the influence of food availability on parental behavior and depredation of juvenile hawks.

\section{Study Area ANd Methods}

We studied a Ferruginous Hawk population in the West Desert of Utah. This region is the lowest and most easterly portion of the Great Basin Desert, a temperate desert. Approximately 100 narrow mountain ranges are located throughout the West Desert, separated by broad alluvial basins. The climate is cold in winter but warm in summer, with precipitation increasing with elevation. Because most of the West Desert is below $1800 \mathrm{~m}$ (the base elevation is about $1300 \mathrm{~m}$ ), most of the region is arid to semiarid with mean annual precipitation $<25 \mathrm{~cm}$. Most mountain ranges are dominated by pinyon-juniper (Pinus edulis-Juniperus spp.) forest. Salt desert scrub composed of Atriplex confertifolia, A. canescens, Sarcobatus vermiculatus and shrubsteppe (Artemisia tridentata, Ephedra viridis, Chrysothamnus viscidiflorus) are the dominant vegetation for most of the West Desert. Portions of the West Desert have been used in past Ferruginous Hawk studies (Weston 1969, Howard 1975, Smith and Murphy 1979, Woffinden and Murphy 1983, Kellert 1992). In the western U.S., Ferruginous Hawks typically nest in the pinyon-juniper/shrub steppe ecotone, which provides nest trees near open foraging areas (Olendorff 1993, Ayers et al. 2009). We used information from a GIS database of the West Desert in conjunction with historical nesting data to locate nests from 1997-99. We checked approximately 300 naturally occurring nest structures (e.g., trees, ground, cliff) annually.

We defined an occupied nesting territory as one that was attended by a male and female Ferruginous Hawk and an active nest as one where we observed an egg or young in a nest or an adult in an incubating posture (Steenhof 1987). We monitored occupied nests every 7-10 d until we observed nestlings. Thereafter, we monitored it about every $7 \mathrm{~d}$ until the young were old enough to band (30 d old). Because Ferruginous Hawks can be sensitive to disturbance during the breeding season (White and Thurow 1985), when monitoring nests we did not access nests directly to count eggs or hatchlings, and instead we observed activity at the nest (e.g., nestlings, adult feeding young) from a distance using binoculars. We considered all nestlings in a nest to have fledged when the first one departed from the nest. Of the various methods available for estimating nest success or survival, we used the apparent method (proportion of observed nest attempts that fledged at least one young) because it has yielded an unbiased estimate of success for Ferruginous Hawks in open shrub-steppe habitats (Lehman et al. 1998).

At banding, we aged juvenile Ferruginous Hawks using Moritsch's photographic guide (1985) and attached a USFWS aluminum leg band to each. 
We attached a 12-g transmitter with a mortality switch (Advanced Telemetry Systems, Inc., Isanti, Minnesota, U.S.A.) to the tarsus of at least one nestling from each nest. After transmitter attachment, birds were relocated at least every $1-2 \mathrm{~d}$ in 1997, and every 3-10 d in 1998 and 1999 until the birds died or dispersed from the West Desert. During 1997, we attempted to locate dispersing juvenile hawks using aerial telemetry, but never relocated a bird once we lost its signal from the ground. Apparently, juvenile hawks leave the West Desert soon after dispersing from their natal territory. Hence, birds were located using only ground telemetry techniques during 1998 and 1999.

If we received a mortality signal from a transmitter, we located the transmitter and carcass to determine the cause of death. We attributed the cause of death to predation if we found only feathers and bones, starvation if the body was emaciated, and unknown if the body was intact or scavenged. We assumed that a carcass had been scavenged if there was no blood at the site of wounds. Other sources of mortality that we documented were human-caused (birds shot) and accident (nest collapse). We assumed that the predator responsible for the kill was a mammal if the feather sheaths had been chewed and an avian predator if they had not been chewed.

Time of death was categorized as occurring during the early nestling period if the dead nestling was $<25 \mathrm{~d}$ old, during the late nestling period if the dead bird was 25-50 d old, and during the fledgling period if the dead bird was $>50 \mathrm{~d}$ old. We determined the average age at fledging for Ferruginous Hawks by pooling telemetry data from all $3 \mathrm{yr}$. If $>1$ bird died at a nest, we categorized the nest using the average age of the young at the time of death. The fledgling period was defined as the period from fledging until juvenile hawks dispersed from the natal area. Dispersal was defined as the first day that a radio-tagged juvenile was not located within its parents' territory (i.e., $>2 \mathrm{~km}$ away from its nest).

We recorded the presence/absence and response of Ferruginous Hawks when we came within $200 \mathrm{~m}$ of their nest. Presence/absence was considered an index to adult attentiveness and response was considered an index to nest defense behavior. Other studies of nest defense behavior by breeding raptors have used humans as a predator (White and Thurow 1985, Andersen 1990, Keeley and Bechard 2011), which is reasonable because persecution of raptors by humans (e.g., shooting mortality) is well documented (Newton 1979, Keeley and Bechard
2011). During our study, two pairs of Ferruginous Hawks in our study area failed to reproduce because the offspring were shot. During each of our nest visits, we noted if adult Ferruginous Hawks were within $200 \mathrm{~m}$ of the nest. When an adult was observed, we ranked the intensity of its defensive behavior. We classified defensive behavior as zero if the bird(s) remained perched and did not vocalize during our visit, one if it left a perch and soared silently in the area, two if it soared above us and vocalized, and three if it dove at us and vocalized. If both adults were seen, the nest defense of each bird was assigned a rank.

Annual changes in food availability were assessed using the Utah Division of Wildlife Resources lagomorph count data for the West Desert. These surveys have been conducted annually since 1989 and began at sunrise between July and August on established $70-\mathrm{km}$ routes. Surveys were not conducted during inclement weather. These surveys provided a single value of lagomorph abundance each year, and a sample size of $3 \mathrm{yr}$ was not large enough for us to use statistics to compare nest success or juvenile mortality to lagomorph abundance.

For data expressed as proportions, we used chisquare tests to make yearly comparisons. When comparing depredation rates among years or the proportion of nests that produced hatchlings, we used a Fisher's exact test instead of a chi-square test because some of the observed or predicted values were $<5$ (SAS Institute Inc. 1987a). We used a oneway ANOVA (SAS Institute Inc. 1987a) to compare annual changes in brood sizes at hatching and fledging. We conducted this analysis first using all nests and then using only nests where at least one egg hatched. We compared survival rates of juvenile Ferruginous Hawks among years using the nonparametric procedure LIFETEST (SAS Institute Inc. 1987b). Procedure LIFETEST creates a probability distribution over time and uses the Log-Rank and Wilcoxon tests to evaluate differences in the distribution of survival patterns of birds. Only radiotagged juveniles were included in the analysis of fledgling survival because the fate of unmarked birds was unknown.

We conducted four statistical tests to evaluate adult behavior near the nest and its potential influence on the probability that juveniles were depredated. First, to assess the influence of adult nest attendance on juvenile depredation, we used PROC GENMOD to evaluate differences among years in the proportion of our nest visits when at least one adult was observed. This program fits a generalized 
linear model using maximum likelihood estimation (SAS Institute Inc. 1987b). We conducted this analysis for the early nestling, late nestling, and fledgling period. Second, we compared the proportion of visits when at least one adult was observed during these three periods among years using PROC GENMOD, where nest was the repeated measure. Third, we used a nonparametric ANOVA (Kruskal-Wallis test) to determine if nestlings and fledglings were depredated less at nests where parents exhibited higher levels of nest defense intensity. Nest defense intensity for this analysis was an index generated from our ranked scores of adult nest defense intensity; we compared the average ranked nest defense score for each nest. Finally, we calculated correlations to determine if there was an association between number of our nest visits and nest defense intensity. We used an alpha level of 0.05 and report mean \pm standard error for all statistical tests, unless otherwise noted.

\section{Results}

During 1997, 1998, and 1999, we located and monitored 100 territories that were occupied by Ferruginous Hawks; $80 \%$ of these had an active nest (Table 1). Over $95 \%$ of the active nests in our study area were located in juniper trees approximately 2.5 to $4 \mathrm{~m}$ tall. The percentage of occupied territories that contained an active nest did not vary among years $\left(\chi^{2}=0.18\right.$, df $\left.=2, P=0.91\right)$.

Across all years, $91 \%$ of active nests produced at least one hatchling, and $67 \%$ of nests with hatchlings produced at least one fledgling. There was a significant difference among years in the proportion of nests that produced a hatchling (Fisher's exact probability test, $\mathrm{df}=2, P=0.03$ ) and in the proportion of nests with hatchlings that produced at least one fledgling $\left(\chi^{2}=6.55\right.$, $\left.\mathrm{df}=2, P=0.04\right)$. Both of these values were highest during 1999. Brood size at hatching did not differ significantly among years but brood size at fledging did (Table 2).

During all years, 202 Ferruginous Hawk hatchlings were produced, and of these, 58\% survived to fledging (Table 1). The percentage of hatchlings that survived to fledging varied among years $\left(\chi^{2}=\right.$ 42.27, $\mathrm{df}=2, P<0.001)$. We radio-tagged 46 Ferruginous Hawk fledglings (10 during 1997, 13 during 1998, and 23 during 1999); 33 (72\%) survived the fledgling period and dispersed from their natal territory. Survival during the fledgling period differed among years $\left(\chi^{2}=7.64\right.$, df $\left.=2, P=0.02\right)$ and was highest during 1999 (Fig. 1). Across all
Table 1. Number of occupied nesting territories, nests with eggs, nests with hatchlings, and nests with fledglings for Ferruginous Hawks nesting in Utah's West Desert during 1997,1998 , and 1999, along with the total number of nestlings and fledglings that were hatched.

\begin{tabular}{lcccc}
\hline \multicolumn{1}{c}{ ReProductive PARAMETER } & 1997 & 1998 & 1999 & TOTAL \\
\hline No. occupied nesting territories & 29 & 32 & 39 & 100 \\
No. nests with eggs & 23 & 25 & 32 & 80 \\
No. nests with nestlings & 21 & 20 & 32 & 73 \\
$\begin{array}{l}\text { No. nests with fledglings } \\
\text { Total no. of nestlings hatched }\end{array}$ & 58 & 54 & 26 & 49 \\
$\begin{array}{l}\text { Total no. of nestlings that } \\
\quad \text { survived to fledge }\end{array}$ & 16 & 29 & 73 & 118 \\
$\quad \begin{array}{l}\text { Total no. of nestlings that died } \\
\quad \text { before fledging }\end{array}$ & 42 & 25 & 17 & 84 \\
\hline
\end{tabular}

years, $42 \%$ of hatchlings survived long enough to disperse from their natal territory. Most juveniles died during the late nestling $(58 \%)$ and fledgling $(24 \%)$ period and mortality was lowest early in the nestling period (18\%). However, it is possible that we failed to record mortality events during the early nestling period as we elected to monitor nests from a distance and not access them directly during this time, so the exact numbers of eggs and young hatchlings were unknown. There was no difference in the timing of mortality among years.

We did not statistically compare the depredation rate during the early nestling period among years because we did not record any nestling depredation during this period in any year of the study. The depredation rate during the late nestling period differed significantly among years (Fisher's exact probability test, $\mathrm{df}=2, P=0.04$ ), and was lowest during 1999 and highest during 1997 when over half of all juveniles were depredated (Fig. 2). The depredation rate during the fledgling period was significantly different among years (Fisher's exact probability test, $\mathrm{df}=2, P=0.02$ ) and was lowest during 1999 (Fig. 2).

Nestling and fledgling Ferruginous Hawks in the West Desert were killed by both mammalian and avian predators. We attributed about $60 \%$ of all depredation events to avian predators, and in 1997 we had evidence the Golden Eagle (Aquila chrysaetos) was one of the avian predators when we tracked a mortality radio signal to an active Golden Eagle nest. After the eagles fledged, we returned and recovered the radio transmitter and two additional USFWS bands that we had placed on nestling Ferruginous Hawks from two different nests. During 
Table 2. Reproductive rate of Ferruginous Hawk nests located in Utah's West Desert during 1997, 1998, and 1999; $n$ is the number of occupied nesting territories (rows 1 and 2), number of nests that contained at least one nestling (row 3), or number of nests that contained at least one fledgling (row 4). Each $P$ value is the result of a statistical test to determine if the parameter in that row differed significantly among years (1997, 1998, and 1999).

\begin{tabular}{|c|c|c|c|c|c|c|c|c|c|c|}
\hline \multirow[b]{2}{*}{ PARAMETER } & \multicolumn{3}{|c|}{1997} & \multicolumn{3}{|c|}{1998} & \multicolumn{3}{|c|}{1999} & \multirow[b]{2}{*}{$P$} \\
\hline & $n$ & MEAN & $\mathrm{SE}$ & $n$ & MEAN & SE & $n$ & MEAN & SE & \\
\hline No. nestlings hatched/occupied nesting territory & 29 & 2.0 & 0.3 & 32 & 1.7 & 0.3 & 39 & 2.3 & 0.3 & 0.35 \\
\hline No. fledglings/occupied nesting territory & 29 & 0.6 & 0.2 & 32 & 0.9 & 0.2 & 39 & 1.9 & 0.3 & $<0.001$ \\
\hline No. nestlings hatched/nest with nestlings & 21 & 2.8 & 0.2 & 20 & 2.9 & 0.3 & 32 & 2.8 & 0.2 & 0.84 \\
\hline No. fledglings/nest with fledglings & 10 & 0.8 & 0.3 & 13 & 1.5 & 0.3 & 26 & 2.3 & 0.2 & $<0.001$ \\
\hline
\end{tabular}

another year, we startled a Golden Eagle from the carcass of a fledgling Ferruginous Hawk.

Adult Ferruginous Hawks were also depredated during the breeding season. In 1997, an adult female was depredated while sitting on the nest during the nestling period. Her nest was located on a ridge-top, and prior to her death, we counted over 50 raptors (mostly juvenile Swainson's Hawks [Buteo swainsoni]) soaring over her nest during the afternoon. During 1998, four adult female Ferruginous Hawks died; we found one of them soon enough after it died to perform a necropsy, which confirmed that it had been killed by a mammalian predator. No adult Ferruginous Hawks died during 1999.
There was no difference among years in our index to adult nest attendance during the early nesting period $(F=1.11, \mathrm{df}=2,57, P=0.33)$, late nestling period $(F=0.94$, $\mathrm{df}=2,49, P=0.39)$, or fledgling period $(F=1.26$, $\mathrm{df}=2,46, P=0.28$; Fig. 3). Therefore, we pooled the data across years and found that adult nest attendance was significantly different among the early nestling, late nestling, and fledgling period $\left(\chi^{2}=23.23, \mathrm{df}=2, P<\right.$ $0.001)$. Attendance was much lower in the late nestling period and the fledgling period compared to early in the nestling period (Fig. 3).

Nest attentiveness did not influence the depredation rate of juvenile Ferruginous Hawks during the late nestling $\left(\chi^{2}=0.62, \mathrm{df}=1, P=0.43\right)$ or the

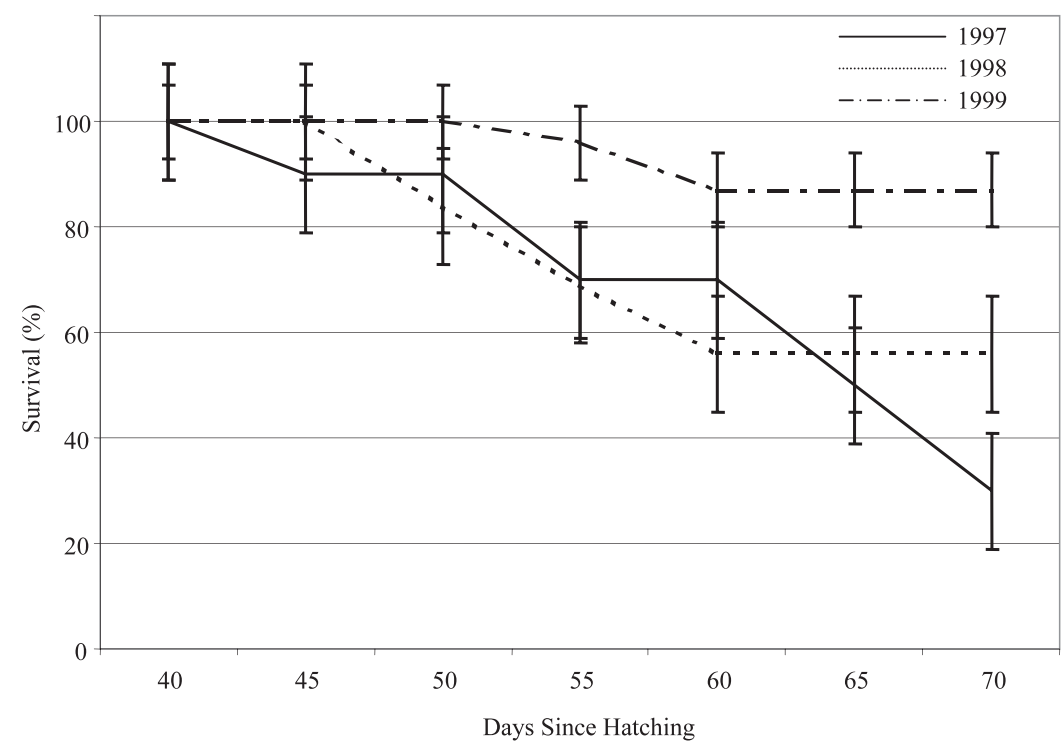

Figure 1. Estimated survival of juvenile Ferruginous Hawks in Utah's West Desert during the fledgling period during 1997, 1998, and 1999 based on the fate of 46 fledglings that were radio-tagged. The fledging period starts on day 50 and continues until the fledglings disperse from their parents' territory. Error bars represent SE. 


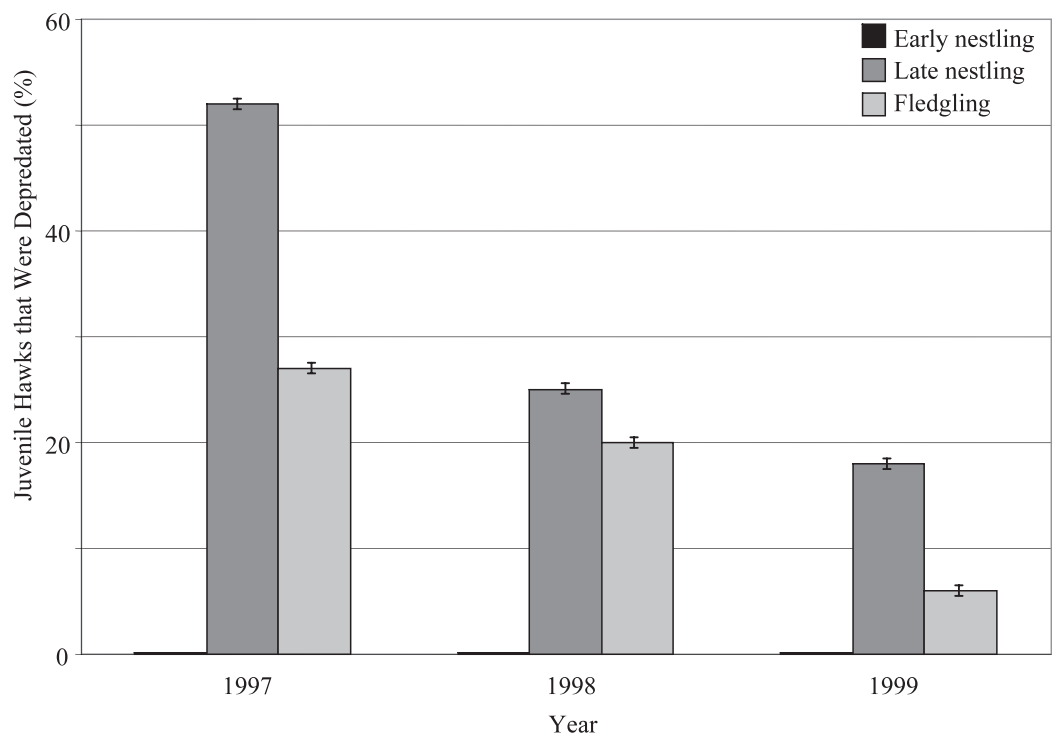

Figure 2. Depredation rate of juvenile Ferruginous Hawks in Utah's West Desert during the early nestling (1-25 d), late nestling (25-50 d), and fledgling period (>50 d) during 1997, 1998, and 1999. Note that no hawks were depredated during the early nestling period during any year of the study, and error bars represent SE.

fledgling period $\left(\left(\chi^{2}=1.49\right.\right.$, $\left.\mathrm{df}=1, P=0.22\right)$. Likewise, our index of nest-defense intensity also did not influence the depredation rate during the late nestling $\left(\chi^{2}=0.69\right.$, df $\left.=1, P=0.41\right)$ or fledgling $\left(\chi^{2}=1.07\right.$, $\left.\mathrm{df}=1, P=0.30\right)$ period.
Finally, there was no correlation between intensity of nest defense and the number of our nest visits during the late nestling (adjusted $r=-0.03 ; P=$ 0.72 ) or the fledgling period (adjusted $r=0.02$; $P=0.22)$.

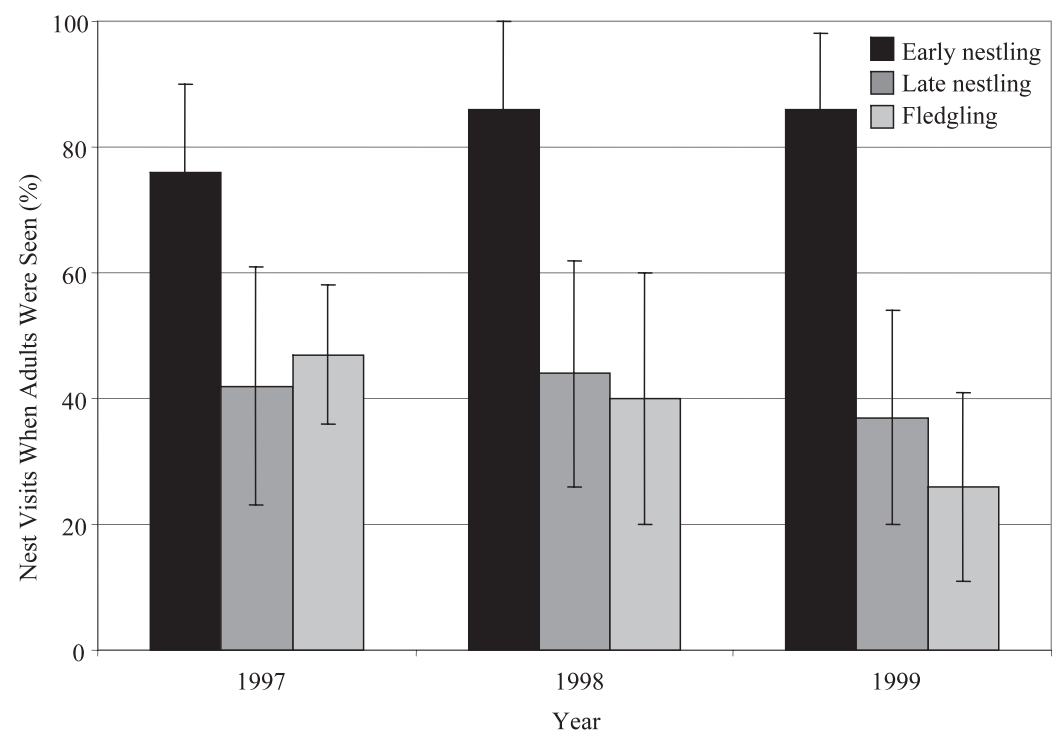

Figure 3. Percent of nest visits when adult Ferruginous Hawks in Utah's West Desert were seen (an index to adult attendance) during the early nestling (1-25 d), late nestling (25-50 d), and fledgling period (>50 d) during 1997, 1998, and 1999. Error bars represent SE. 


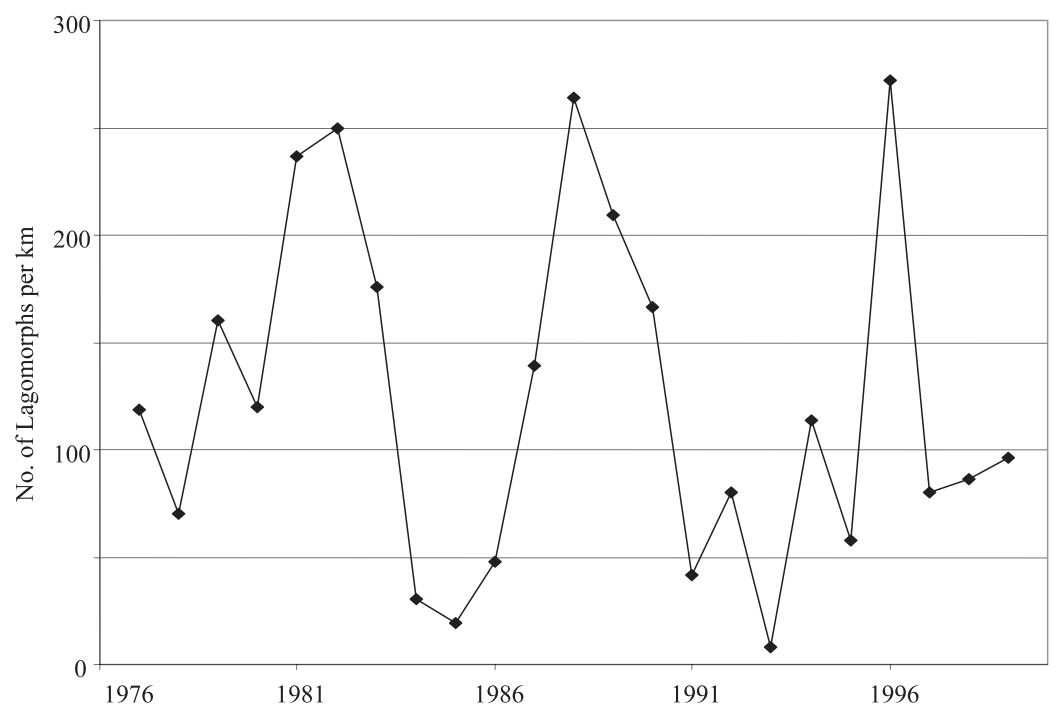

Figure 4. Average number of lagomorphs observed per km of road surveyed throughout Utah from 1977-99 (unpubl. annual report, Utah Division of Wildlife Resources).

The total number of rabbits observed in the area around our study area increased each year, from $0.0006 / \mathrm{km}^{2}$ in 1997 to $0.04 / \mathrm{km}^{2}$ in 1998 , and $0.10 / \mathrm{km}^{2}$ in 1999 . An increasing trend in lagomorph abundance during these years was also observed for the entire state of Utah (Fig. 4). We observed the same trend (i.e., increasing during each year of the study) in the number of territories occupied by Ferruginous Hawks, the number of active nests, the proportion of hatchlings that survived to fledging, and number of fledglings that survived to disperse, whereas the proportion of nests that produced at least one hatchling stayed relatively constant.

\section{Discussion}

Reproductive success of Ferruginous Hawks increased substantially during the course of our study. The abundance of rabbits also greatly increased from 1997 to 1999, suggesting that Ferruginous Hawk reproductive success was closely linked to food availability in the West Desert. A strong association between prey availability and Ferruginous Hawk reproductive success has been documented for other regions as well (Bechard and Schmutz 1995, Clark and Houston 2008, Schmutz et al. 2008). For example, Smith and Murphy (1979) reported a territory occupancy rate of nearly $90 \%$ for Ferruginous Hawks in central Utah when lagomorph density was high, compared to $43 \%$ occupancy during years of low food availability. Similar fluctuations in reproductive success associated with prey availability have been reported in Idaho (Thurow et al. 1980), Montana (Zelenak and Rotella 1997) and Canada (Schmutz et al. 2008).

Many researchers have concluded that decreased food availability led to higher starvation rates of juveniles, which lowered reproductive success (Bechard and Schmutz 1995). However, few studies have reported the cause of death for nestlings or fledglings because juvenile hawks were rarely radiotagged, and so the final fate of birds that disappeared was unknown. We were able to determine the fate of most juveniles in our study because we radio-tagged them. Depredation was by far the most common cause of mortality for juveniles during both the nestling and fledgling periods. Other researchers have reported depredation among juvenile Ferruginous Hawks. In Montana, Zelenak et al. (1997) found four juveniles that died soon after fledging; of these, one died of unknown causes and the other three were brood-mates that all died on the same day and had large head wounds that were consistent with those caused by Great Horned Owls (Bubo virginianus). Harmata et al. (2001) reported the death of four juvenile Ferruginous Hawks that died prior to dispersing from their natal areas in Montana; the authors believed that two died of unknown causes and two were killed by mammalian predators. Keough (2006) monitored the fate of 58 juvenile Ferruginous Hawks in Utah's Uintah Basin and determined that 
31 died before dispersing from their natal territories. Of these, 17 were killed by avian predators, 5 were killed by mammalian predators, 3 were killed by an unknown predator, 5 died from natural causes (injury, exposure, disease, or starvation), and 1 from an unknown cause.

Our study raised the question of why depredation rates of juvenile Ferruginous Hawks increased during poor-food years. One possibility is that increased food availability enabled parents to spend less time foraging and more time near the nest where they could deter predators (Martin 1992). However, we did not find any support for our hypothesis that changes in parental behavior are the underlying mechanism that linked increased food availability to decreased depredation of juvenile hawks. For example, we did not detect any increase in parental nest attendance as food availability increased. We also found no relationship between juvenile depredation and parental nest attendance or intensity of nest defense. As a caveat, we acknowledge that our index to parental attendance was based on brief "snapshots" of adult presence/ absence when we visited nests, rather than a true observational record of attendance.

Another explanation for the decreased depredation of juvenile Ferruginous Hawks during years when lagomorph densities are higher may be the foraging behavior of Golden Eagles. This large raptor nests throughout the West Desert, and lagomorphs typically account for over $80 \%$ of the Golden Eagle diet. Reproductive success of Golden Eagles in Idaho and Utah, like that of Ferruginous Hawks, has been closely associated with lagomorph abundance (Murphy 1974, Beecham and Kochert 1975). Golden Eagle nest occupancy and reproductive success in the West Desert from 1997-99 were similar to those of Ferruginous Hawks. Forty-six, 66, and 102 nests were active in 1997, 1998, and 1999, respectively. Nest success during these years was 30\%, 37\%, and $57 \%$ (Kellert 2000). This increasing trend is noteworthy because it excludes the possibility that the decreasing rates of depredation among juvenile Ferruginous Hawks in the West Desert from 199799 were attributable to decreased abundance of Golden Eagles.

Based on prey remains, Kellert (2000) found that Golden Eagles in the West Desert killed birds of eight diurnal raptor species (including the Ferruginous Hawk) and five owl species. Buteo species have also been identified in the prey remains of other Golden Eagle populations (McGahan 1967, Ellis et al. 1999). We also documented apparent Golden Eagle depredation of juvenile Ferruginous Hawks in 1997. Hence, Ferruginous Hawks are a potential alternative prey source for Golden Eagles in the West Desert. However, eagles attempting to capture young hawks risk injury or even death from Ferruginous Hawk parents. Hence, juvenile Ferruginous Hawks are probably not a preferred prey of eagles, and the presence of an adult near the nest is likely a sufficient deterrent for predators under normal circumstances. However, Golden Eagles may be more willing to risk injury by preying upon juvenile Ferruginous Hawks when their primary prey are unavailable. Elsewhere Golden Eagles have survived on hedgehogs (Erinaceus europaeus; Högström and Wiss 1992), hawks, and herons (Spofford 1971) when their principal prey is low in abundance. We hypothesize that during 1997 when lagomorph density was low, Golden Eagles took more juvenile Ferruginous Hawks, resulting in the high depredation rates that year, but eagles took fewer juveniles in 1998 and 1999 when lagomorph abundance increased. Hence, low reproductive output of Ferruginous Hawks in Utah's West Desert during years when lagomorph densities were low was more a product of depredation by food-limited predators than direct starvation.

\section{ACKNOWLEDGMENTS}

Funding for this research was provided by Hill Air Force Base, Utah Division of Wildlife Resources, Utah Chapter of the Wildlife Society, Utah State University Ecology Center, Women and Gender Research Institute at Utah State University, and the Utah Agricultural Experiment Station (journal paper number 8400). We thank Ann Brown, Theresa Doumitt, Susan Durham, Mark Fuller, Kirk Gardner, Frank Howe, Tom Maechtle, Jim Parrish, Kim Sullivan, Mark Szczpinski, and Pat Kennedy for the help collecting the data and for providing advice and guidance.

\section{Literature Cited}

ANDERSEN, D.E. 1990. Nest-defense behavior of Red-tailed Hawks. Condor 92:991-997.

Ayers, L., B. OAKLeAF, AND T. Filipi. 2009. Distribution and abundance of breeding Ferruginous Hawk pairs in southcentral Wyoming. Completion report. Pages 72-85 in A. Orabona [ED.], Threatened, endangered, and nongame bird and mammal investigations. Wyoming Game and Fish Department, Laramie, WY U.S.A.

Bechard, M.J. And J.K. Schmutz. 1995. Ferruginous Hawk (Buteo regalis). In A. Poole and F. Gill [EDS.], Birds of North America, No. 172. Academy of Natural Sciences, Philadelphia, PA and the American Ornithologists' Union, Washington, DC U.S.A. 
BeECHAM, J.J. AND M.N. KoCheRT. 1975. Breeding biology of the Golden Eagle in southwestern Idaho. Wilson Bulletin 87:506-513.

Cartron, J.-L.E., P.J. Polechia, Jr., And R.R. Cook. 2004. Prey of nesting Ferruginous Hawks in New Mexico. Southwestern Naturalist 49:270-276.

Clark, J.B. AND C.S. Houston. 2008. Ferruginous Hawks successfully fledge six chicks. Journal of Raptor Research 42:152-153.

Conover, M.R. 2007. Predator-prey dynamics: the role of olfaction. CRC Press, Boca Raton, FL U.S.A.

Ellis, D.H., P. Tsengeg, P. Whitlock, And M.H. Ellis. 1999. Predators as prey at a Golden Eagle (Aquila chrysaetos) eyrie in Mongolia. Ibis 141:139-142.

Giovanni, M.D., C.W. Boal, And H.A. Whitlaw. 2007. Prey use and provisioning rates of breeding Ferruginous and Swainson's hawks on the southern Great Plains, USA. Wilson Journal of Ornithology 119:558-569.

Gross, J.W., L.C. Stoddart, And F.H. Wagner. 1974. Demographic analysis of a northern Utah jackrabbit population. Wildlife Monographs 40:1-68.

Harmata, A.R., M. Restani, G.J. Montopoli, J.R. Zelenak, J.T. Ensign, and P.J. Harmata. 2001. Movements and mortality of Ferruginous Hawks banded in Montana. Journal of Field Ornithology 72:389-398.

Högström, S. AND L.E. Wiss. 1992. Diet of the Golden Eagle (Aquila chrysaetos) in Gotland, Sweden during the breeding season. Ornis Fennica 69:39-44.

HowARD, R.P. 1975. Breeding ecology of the Ferruginous Hawk in northern Utah and southern Idaho. M.S. thesis, Utah State University, Logan, UT U.S.A.

Keeley, W.H. And M.J. Bechard. 2011. Flushing distances of Ferruginous Hawks nesting in rural and exurban New Mexico. Journal of Wildlife Management 75:10341039.

KELLERT, K.R. 1992. 1992 central region Ferruginous Hawk survey. Unpubl. rep. Utah Division of Wildlife Resources, Salt Lake City, UT U.S.A.

- 2000. Golden Eagle nesting survey report for the central Utah study area, February-July 2000. Unpubl. rep. Utah Division of Wildlife Resources, Salt Lake City, UT U.S.A.

KeOugh, H.L. 2006. Factors influencing breeding Ferruginous Hawks (Buteo regalis) in the Uintah Basin, Utah. Ph.D. dissertation. Utah State University, Logan, UT U.S.A.

Lehman, R.N., L.B. Carpenter, K. Steenhof, and M.N. KocherT. 1998. Assessing relative abundance and reproductive success of shrubsteppe raptors. Journal of Field Ornithology 69:244-256.

MARTIN, T.E. 1992. The interaction of nest predation and food limitation in reproductive strategies. Current Ornithology 9:163-197.

MCGAHAN, J. 1967. Quantified estimates of predation by a Golden Eagle population. Journal of Wildlife Management 31:496-501.
MORITSCH, M.Q. 1985. Photographic guide for aging nestling Ferruginous Hawks. USDI Bureau of Land Management, Boise, ID U.S.A.

MurPhy, J.R. 1974. Status of a Golden Eagle population in central Utah. Raptor Research 3:91-96.

Newton, I. 1979. Population ecology of raptors. Buteo Books, Vermillion, SD U.S.A.

1991. Pages 3-21 in C.M. Perrins, J.D. Leberton, and G.M. Hiro [EDs.], Bird population studies. Oxford Univ. Press, Oxford U.K.

OlendorfF, R.R. 1993. Status, biology, and management of Ferruginous Hawks: a review. Raptor Research and Technical Assistance Center, special report. USDI Bureau of Land Management, Boise, ID U.S.A.

SAS InSTITUTE INC. 1987a. SAS System for Elementary Statistical Analysis. SAS Institute Inc., Cary, NC U.S.A.

SAS INSTITUTE INC. 1987b. SAS/STAT guide for personal computers. SAS Institute Inc., Cary, NC U.S.A.

Schmutz, J.K., D.T.T. Flockhard, C.S. Houston, AND P.D. McLoughlin. 2008. Demography of Ferruginous Hawks breeding in western Canada. Journal of Wildlife Management 72:1352-1360.

Smith, D.G. AND J.R. MuRPHy. 1979. Breeding responses of raptors to jackrabbit density in the eastern Great Basin Desert of Utah. Raptor Research 13:1-14.

一 - - AND N.D. Woffinden. 1981. Relationships between jackrabbit abundance and Ferruginous Hawk reproduction. Condor 83:52-56.

SPOFFORD, W.R. 1971. The breeding status of the Golden Eagle in the Appalachians. American Birds 25:37 .

Steenhof, K. 1987. Pages 157-170 in B.A. Giron Pendleton, B.A. Millsap, K.W. Kline, and D.M. Bird [EDs.], Raptor management techniques manual. National Wildlife Federation, Washington, DC U.S.A.

Thurow, T.L., C.M. White, R.P. Howard, And J.F. SulliVAN. 1980. Raptor ecology of Raft River Valley. EG\&G Idaho Inc., Idaho Falls, ID U.S.A.

WARD, J.M. AND P.L. KenNEDY. 1994. Approaches to investigating food limitation hypotheses in raptor populations: an example using the Northern Goshawk. Studies in Avian Biology 16:114-118.

— AND — 1996. Effects of supplemental food on size and survival of juvenile Northern Goshawks. Auk 113:200-208.

Weston, J.B. 1969. Nesting ecology of the Ferruginous Hawk Buteo regalis. Brigham Young University Scientific Bulletin Biological Series 10:25-36.

White, C.M. And T.L. Thurow. 1985. Reproduction of Ferruginous Hawks exposed to controlled disturbance. Condor 87:14-22.

Woffinden, N.D. And J.R. Murphy. 1977. Population dynamics of the Ferruginous Hawk during a prey decline. Great Basin Naturalist 37:411-425.

_ AND —. 1983. Ferruginous Hawk postfledging activities. North American Bird Bander 8:94-96. 
AND

1989. Decline of a Ferruginous Hawk population: a 20-year summary. Journal of Wildlife Management 53:1127-1132.

ZELENAK, J.R. AND J.J. Rotella. 1997. Nest success and productivity of Ferruginous Hawks in northern Montana. Canadian Journal of Zoology 75:1035-1041.
, AND A.R. HARMATA. 1997. Survival of fledgling Ferruginous Hawks in northern Montana. Canadian Journal of Zoology 75:152-156.

Received 29 January 2012; accepted 1 October 2012 Associate Editor: Jessi L. Brown 